\title{
cDNA Cloning of a Bovine Insulin-like growth factor-1 from Egyptian Buffalos and Expression of its Recombinant Protein in Escherichia coli
}

\author{
[Clonagem de cDNA de um fator-1 de crescimento semelhante à insulina bovina de \\ búfalos egípcios e expressão de sua proteína recombinante em Escherichia coli] \\ Mourad A.M. Aboul-Soud ${ }^{1,2}$ \\ ${ }^{1}$ College of Applied Medical Sciences - King Saud University - Riyadh, Saudi Arabia \\ ${ }^{2}$ Cairo University Research Park - Cairo University - Giza, Egypt
}

\begin{abstract}
Insulin-like growth factor-1 (IGF-1) is regarded as a crucial clinically significant therapeutic agent against several pathological conditions. Recently, recombinant DNA (rDNA) technology has enabled the production of many drugs of rDNA-origin including $I G F-1$. Securing a readily available supply of IGF-1 is invaluable to clinical research and biotechnological domains. In this work, the cloning of a full-length bovine IGF-1 cDNA and the successful expression of its cognate recombinant IGF-1 protein is reported. Single-strand cDNA was prepared from liver tissues, through the specific reverse transcription (RT) of $I G F-1$ mRNA. Subsequently, a PCR amplicon of $\sim 543 \mathrm{bp}$ was successfully amplified. Recombinant pTARGET ${ }^{\mathrm{TM}}$ vector harboring $I G F-1$ insert was successfully cloned into competent $E$. coli JM109 cells. SDS-PAGE analysis revealed that the recombinant IGF-1 has been expressed at the expected size of $7.6 \mathrm{kDa}$. The outcome provides a robust basis for transecting the recombinant pTARGET $^{\mathrm{TM}}$ vector, harboring the $I G F-1$ cDNA insert, into mammalian cells. Optimal initial glucose concentration was found to be $10 \mathrm{~g} / \mathrm{l}$ with corresponding protein concentration of $6.2 \mathrm{~g} / \mathrm{l}$. The proliferative biological activity crude recombinant IGF-1 protein was verified on HeLa cell lines. This is envisaged to facilitate large-scale production of recombinant IGF-1 protein, thereby enabling thorough investigation of its clinical and pharmaceutical effects.
\end{abstract}

Keywords: protein expression, insulin-like growth factor 1, bovine, Bos taurus, recombinant, RT-PCR

\section{RESUMO}

O fator de crescimento semelhante à insulina-1 (IGF-1) é considerado um agente terapêutico clinicamente significativo contra várias condições patológicas. Recentemente, a tecnologia de DNA recombinante ( $r D N A$ ) permitiu a produção de muitos medicamentos de origem rDNA, incluindo o IGF-1. Garantir um suprimento prontamente disponível de IGF-1 é inestimável para pesquisas clínicas e domínios biotecnológicos. Neste trabalho, relata-se a clonagem de um cDNA de IGF-1 bovino de comprimento total e a expressão bem-sucedida de sua proteína IGF-1 recombinante cognata. O cDNA de cadeia simples foi preparado a partir de tecidos do fígado, por meio da transcrição reversa específica (RT) do mRNA de IGF-1. Posteriormente, um amplificador de PCR de 543pb foi amplificado com sucesso. $O$ vetor pTARGET TM recombinante contendo a inserção de IGF-1 foi clonado com sucesso em células competentes E. coli JM109. A análise por SDS-PAGE revelou que o IGF-1 recombinante foi expresso no tamanho esperado de 7,6kDa. O resultado fornece uma base robusta para a transferência do vetor pTARGETTM ${ }^{T M}$ recombinante, abrigando a inserção de cDNA de IGF-1 em células de mamíferos. Verificou-se que a concentração inicial ideal de glicose é $10 \mathrm{~g} / \mathrm{L}$, com a concentração de proteína correspondente de 6,2g/L. A proteína IGF-1 recombinante bruta de atividade biológica proliferativa foi verificada nas linhas celulares HeLa. É previsto que isso facilite a produção da proteína IGF-1 recombinante em larga escala, permitindo, assim, uma investigação completa dos seus efeitos clínicos e farmacêuticos.

Palavras-chave: expressão proteica, fator de crescimento semelhante à insulina-1, bovino, Bos Taurus, recombinante, $R T-P C R$

Recebido em 1 de agosto de 2019

Aceito em 11 de dezembro de 2019

E-mail: maboulsoud@ksu.edu.sa 


\section{INTRODUCTION}

Insulin-like growth factors (IGFs) constitute a family of structurally-associated polypeptides controlling several developmental aspects in mammalians. Expression of IGFs gene family and their cognate mRNA transcripts have been observed in tissues and embryos of diverse species (Naicy et al., 2017). To this end, mounting evidence suggest that the IGFs play a crucial part during early growth and development both in vitro and in vivo (Jansen et al., 1983). In vivo, IGFs have been implicated in multifaceted biological processes including development, growth, metabolism and reproduction (Stewart and Rotwein, 1996). Insulin-like growth factor 1 (IGF-1; also called somatomedin C), as an essential constituent of the somatotropic axis, critically orchestrates hormonal signaling impacting growth, reproduction, cell proliferation and fetal development. IGF-1 potentiates mitogenic and myogenic processes during muscular growth and development (Ewton et al., 1994; Florini et al., 1996; Davis and Semmen., 2006), whereas it stimulates reproduction through enhancing embryonic development, ovarian function, folliculogenesis and steroidogenesis (Lucy, 2000; Spicer et al., 2002; Behl and Kaul, 2002; Velazquez et al., 2008).

In vitro findings support the hypothesis that culture media supplemented with high concentrations of IGF-1 mixed in granulose cells and estrous cow serum can ameliorate the development of embryos maintained in vitro. In this context, supplementation of in vitro maturation (IVM) culture medium with IGF1 is reported to increase from $35 \%$ to $60 \%$ proportion of human embryos developed during the blastocyst stage (Lighten et al., 1998). Supplementation of (IVM) medium with IGF-1 at a concentration of $100 \mathrm{ng} / \mathrm{ml}$ exhibited stimulation of oocyte maturation in buffalo (Pawsche et al., 1998). While the supplementation of bovine IVM medium with IGF-1 exerted no effect on the embryonic cleavage rate, low and high concentrations (i.e., 50 and $500 \mathrm{ng} / \mathrm{ml}$ ) significantly increased blastocyst yields (Markkula and Makarevich, 2001).

The IGF-1 is a member of the insulin gene family that also includes insulin, relaxin and many lower invertebrate peptides (Blundell and Humbel, 1980). Despite the structural and functional similarities, IGF-1 possesses a more pronounced growth-promoting activity than insulin. Bovine IGF-1 is a 70-amino acids, basic and globular single-chain polypeptide having a molecular weight of $7.6 \mathrm{kDa}$. While the bovine IGF-1 cDNA shares $93 \%$ identity with the human sequence, the cognate amino acid sequence is $96 \%$ conserved compared to the human one (Fotsis et al., 1990).

Three intra-molecular disulfide bridges maintain the tertiary structure of the IGF-1 molecule (Watson et al., 1999). Bovine, porcine and human IGF-1 proteins are identical. IGF-1 is predominantly produced by the liver, however, several tissues synthesize IGFs at specific developmental periods. Mapping efforts of $I G F$ $l$ have assigned it to a single gene locus on bovine chromosome 5 and the long arm of chromosome 12 in humans (Brissenden et al., 1984). Both IGF-1 and IGF2 are secreted as prohormones with similarities in their biological role; however they exhibit significant variations in their spatio-temporal expression patterns in vivo (Froesch et al., 1985).

In particular, IGF-1 is expressed in embryos and is predominantly produced in hepatocytes under the regulation of growth hormone. IGF2, by contrast, is synthesized primarily in diverse tissues at the embryonic and fetal stages of mammalian growth. This implies that the IGFs may possess dual in vivo responsibilities acting both as paracrine and endocrine effectors, whereby regulating the growth of various tissues (Froesch et al., 1985).

Recently, recombinant DNA (rDNA) technology has enabled the production of many drugs of rDNA-origin including the human IGF-1 that were approved by the U.S. FDA in 2006 (Jafari et al., 2014). Increlex ${ }^{\circledR}$ (Mecasermin) is a recombinant IGF-1-based drug that is prescribed for dwarfed children who have been diagnosed with growth hormone or IGF-1 (i.e. Laron syndrome) deficiencies (Choi et al., 2003). Moreover, IGF-1 have been advocated as a potential cure for several other pathological conditions, including osteoporosis Locatelli and Bianchi., 2014), diabetes (Barner et al., 2012), aging (Anisimov and Bartke, 2013) and AIDS muscle wasting (Haugaard et al., 2004). 
In the light of its diverse medical and applied applications, securing a readily-available supply of IGF-1 is invaluable to clinical research and biotechnological domains. It is noteworthy to point out that the production of recombinant proteins in microorganisms, e.g. bacterial strains such as Escherichia coli (E. coli), is considered a valuable approach for the commercialization of medical products for multiple reasons, namely: cost-effectiveness, high throughput, maximized yield of protein production $(\geq 50 \%$ of total cellular protein), amenability of cloning cassettes and straightforward culturing protocols (Jafari et al., 2014; Aboutalebi et al., 2018). Moreover, handling of recombinants proteins is characterized by higher safety prospects as opposed to handling body fluids obtained directly from individuals (Wong et al., 1988). Therefore, the present work is aiming to clone the $I G F-1$ gene from Egyptian buffalo, followed by bona fide expression of its encoded protein in E. coli. This work highlights the potential use of recombinant IGF-1 for the enhancement of embryonic development in cattle.

\section{MATERIALS AND METHODS}

E. coli JM109 High Efficiency Competent Cells was obtained from Promega (Madison, WI USA) employed for the transformation serving as host for recombinant plasmid and recombinant protein expression. The genotype of $E$. coli JM109 is recA1, endA1, gyrA96, thi, hsdR17 $\left(\mathrm{r}_{\mathrm{K}^{-}}, \mathrm{m}_{\mathrm{K}+}\right), \operatorname{rel} \mathrm{A} 1, \sup \mathrm{E} 44, \Delta($ lac-pro $\mathrm{AB}),\left[\mathrm{F}^{\prime}\right.$, traD36, proAB, lac $\left.\mathrm{I}^{\mathrm{q}} \mathrm{Z} \Delta \mathrm{M} 15\right]$ (Messing et al., 1981). pTARGET ${ }^{\mathrm{TM}}$ Mammalian Expression Vector System was purchased from Promega (Madison, WI USA) and employed as cloning vector.

All experimental procedures were conducted according to the guidelines of the Institutional Animal Ethics Committee of Cairo University. Bovine liver samples were sourced from ElSharkawy slaughterhouse, Shubra El-Khima, Qalyubia Governorate, Egypt. Liver tissues were obtained from young male hybrid brown Buffalos (Bos taurus; Bovidae) aged 9 to 12 months. Collected liver tissues were rinsed in sterile 1x phosphate-buffered saline (PBS; prepared in nuclease-free water), and rapidly dissected ( 50-100mg) by use of sterile scalpel. RNA Stabilization Reagent (RNAlater ${ }^{\circledR}$ Qiagen, Hilden, Germany) tubes were used for Tissue specimens that were kept at $4^{\circ} \mathrm{C}$ overnight, snapfrozen in liquid nitrogen, and stored at $-80^{\circ} \mathrm{C}$ awaiting RNA extraction (Al-Sheikh et al., 2016).

Liver tissue samples obtained from six buffalos with three technical replicates per sample were analyzed. Briefly, 30-50mg liver tissues were subjected to grinding using Qiagen Tissue Lyser LT in with the help of stainless steel beads and liquid $\mathrm{N}_{2}$ (Al-Sheikh et al., 2016). SV Total RNA Isolation Kit was used to extract total RNA from bovine tissues (Promega, USA) according to the manufacturer's instructions. For estimating the isolated RNA concentration of the tissue specimens, optical density at 260/280nm (OD260, OD280) was recorded using Thermo Fisher Scientific's Fluorometer (Qubit ${ }^{\circledR}$ 2.0, USA) and Peqlab's spectrophotometer (NanoDrop 1000, Peqlab Biotechnologie Germany). Analysis of RNA integrity (RIN) was conducted using the Agilent 2100 Bioanalyzer (Agilent Technologies, Germany) using Nano LabChip analysis kit (RNA 6000 series II) (AlSheikh et al., 2016).

Only $20 \mu 1$ of the solution were used for reverse transcription (RT) reaction by preparing a master mix (MM), to minimize pipetting errors, in $0.5 \mathrm{ml}$ sterile PCR tubes and then centrifuged for a while, thereby dividing $\mathrm{MM}$ into $0.2 \mathrm{ml}$ PCR tubes. Before this, total RNA was thawed on ice and denatured at $65^{\circ} \mathrm{C}$ for $15 \mathrm{~min}$. Other than this, all solutions for RT were also thawed at $65^{\circ} \mathrm{C}$ for $30-60 \mathrm{sec}$, and then stored at ice temperature throughout during the preparation of MM. Care was taken to change pipette tips for each pipetting. For RT reaction, $1 \mu \mathrm{g}$ liver of RNA was pretreated with DNase (Promega, USA) in the sterile tube, mixed gently by tapping, short centrifuged and then transferred to the 96-Well Fast Thermal Cycler (Applied Biosystems ${ }^{\circledR}$ Veriti $\left.{ }^{\circledR}\right)$. The RT reactions were carried out at $25^{\circ} \mathrm{C}$ for $10 \mathrm{~min}$ as well as at $42^{\circ} \mathrm{C}$ for $1 \mathrm{~h}$ and then denatured at $99^{\circ} \mathrm{C}$ for $5 \mathrm{~min}$, finally cooled to $4^{\circ} \mathrm{C}$.

Bovine cDNA was first ice-thawed prior to use, then, 2-fold diluted for subsequent use for PCR. $50 \mu \mathrm{l}$ of the reaction blend was prepared in $200 \mu \mathrm{l}$ PCR tubes containing template cDNA, 1X buffer, dNTPs $(200 \mu \mathrm{M}), I G F-1$-specific primers (IGF-1-F: 5'-ATGGGAAAAATCAGCAGTCTTC- 
3' and IGF-1-R: 5'GGTGTTTAACAGGTAACTCGTG-3', NCBI$\mathrm{X} 15726$ accession number, $0.2 \mu \mathrm{M}$ of each) manufactured by GATC Germany, high fidelity $P f u$ DNA polymerase (1.5 units) and nucleasefree deionized water up to $50 \mu$ total volume. All PCR solutions and reagents were pre-thawed at $65^{\circ} \mathrm{C}$ for $60 \mathrm{sec}$, gently-stirred and then stored on ice during the process. Following a brief centrifugation, $0.2 \mathrm{ml}$ of MM with cDNA in PCR tubes were placed in 96-Well Fast Thermal Cycler (Applied Biosystems ${ }^{\circledR}$ Veriti $\left.{ }^{\circledR}\right)$. A PCR program was conducted with the template cDNA by employing a PCR program as follows: initial denaturation at $96^{\circ} \mathrm{C}$ for $5 \mathrm{~min}, 35$ cycles of $96^{\circ} \mathrm{C}$ for $1 \mathrm{~min}, 57^{\circ} \mathrm{C}$ for $1 \mathrm{~min}, 72^{\circ} \mathrm{C}$ for $1 \mathrm{~min}$, and a final extension step at $70^{\circ} \mathrm{C}$ for $5 \mathrm{~min}$. Deionized water instead of cDNA template was used as a negative control.

PCR products were resolved, electrophoresis was done on agarose gel $(2 \%)$ in $1 \mathrm{X}$ Tris-BorateEDTA (TBE), stained with ethidium bromide, visualized and analyzed in UV-Gel Documentation System (Biometra Biomedizinische Analytik, Germany) (Sambrook et al., 1989). Sanger sequencing was conducted by GATC Biotech (Germany) on ABI Prism model 3730XL (Applied Biosystems) according to the dideoxy chain-termination method as reported elsewhere (Sanger et al., 1977). The sequencing was performed on purified PCR amplicons by use of $I G F-1-F$ as the sequencespecific sense primer.

For cloning, pTARGET ${ }^{\mathrm{TM}}$ (Promega Corporation, Madison, USA) was employed. Prior to cloning, the blunt-end $P f u$-generated $I G F-1$ cDNA was A-tailed using $1 \mu \mathrm{l}$ Taq polymerase (5 units; Promega), 10X reaction buffer with $\mathrm{MgCl}_{2}$, ATP $(0.2 \mathrm{mM})$ and distilled water. This was followed by incubation at $70^{\circ} \mathrm{C}$ for $30 \mathrm{~min}$, and the resultant product was directly used for ligation reaction, with DNA ligase $(1 \mu \mathrm{l}$, 3 Weiss units $/ \mu \mathrm{l}), 10 \mathrm{X}$ Buffer $(1 \mu \mathrm{l})$, vector $(1 \mu \mathrm{l}$, $60 \mathrm{ng} / \mu \mathrm{l})$, PCR amplicon $(4 \mu \mathrm{l}, 50 \mathrm{ng} / \mu \mathrm{l})$ and distilled water $(10 \mu \mathrm{l})$. The mixture was left for overnight incubation at $4^{\circ} \mathrm{C}$ to achieve maximum ligation efficiency. The molar ratio of insert/vector was optimized at 3:1. Transformation of E. coli JM109 was essentially conducted according to standard heat shock procedure (Sambrook et al., 1989). Bona fide transformants were selected and grown overnight on LB/ampicillin $(100 \mu \mathrm{g} / \mathrm{ml}) / \mathrm{IPTG} / \mathrm{X}-\mathrm{Gal}$ plates at $37^{\circ} \mathrm{C}$ and were stored at $4^{\circ} \mathrm{C}$ to facilitate blue/white screening (Sambrook et al., 1989).

White colonies were screened for inserts by direct colony PCR using $I G F-1-F$ and $I G F-1-F$ as according to previously published protocol by us with some modifications (Aboul-Soud et al., 2019). Colonies having $1 \mathrm{~mm}$ in diameter were picked up from agar plates by use of a sterile toothpick and subsequently transferred into $0.5 \mathrm{ml}$ PCR tubes containing $50 \mu \mathrm{l}$ of sterile water. Tubes were briefly vortexed and heated in a heat block at $99^{\circ} \mathrm{C}$ for $5 \mathrm{~min}$ for cell lysis and denaturation of DNases. After removal of cell debris by centrifugation at $12000 \times \mathrm{g}$ for $1 \mathrm{~min}$, $2 \mu \mathrm{l}$ of the supernatant were transferred to a fresh $0.2 \mathrm{ml}$ PCR tubes to do PCR reactions according to the manufacturer's instructions, following the same cycling parameters. Then, $10 \mu \mathrm{l}$ of PCR product was loaded onto a $2 \%$ agarose gel stained with ethidium bromide for electrophoresis at $100 \mathrm{v}$ for $30 \mathrm{~min}$.

Overnight grown cultures reaching an OD of 0.8 were centrifuged and the resultant pellet was suspended in $1 \mathrm{mM}$ DTT. Following homogenization, the resultant homogenate was spun at $12000 x$ g for $10 \mathrm{~min}$. The supernatant was decanted and the remaining pellet was dissolved in buffer containing $0.5 \%$ Triton $^{\mathrm{TM}} \mathrm{X}-100$, $50 \mathrm{mM}$ Tris, 5mM EDTA and $1 \mathrm{mM}$ DTT and subsequently incubated at RT for $30 \mathrm{~min}$. Finally, it was centrifuged at $12000 \mathrm{xg}$ for $20 \mathrm{~min}$, supernatant decanted, and the remaining pellet was re-suspended in $100 \mu \mathrm{l}$ sterile deionized water. Protein concentration of the samples was measured using bovine serum albumin (BSA) as a standard following standard procedure (Lowry, 1951). Proteins were resolved on $12 \%$ Sodium dodecyl sulfate-polyacrylamide gel electrophoresis (SDS-PAGE) (Aboul-Soud $e t$ al., 2019), and gels were stained with Coomassie Brilliant Blue R-250.

E. coli bacterial culture growth was monitored by measuring its turbidity and cell dry weight (CDW). Turbidity was determined at wavelength of $600 \mathrm{~nm}$. Cultures were diluted with physiological sterile $\mathrm{NaCl}$ saline solution to adjust OD values with the range of 0.2 and 0.5 . For CDW determination, broth culture was centrifuged at $4,000 \mathrm{rpm}$ for $10 \mathrm{~min}$, followed by 
washing with deionized water, and finally drying at $100^{\circ} \mathrm{C}$ inside an incubator in order to attain a constant weight. Glucose was added at the initiation of culture at increasing concentrations of $0,5,10,15$, and 20g/l (Aboutalebi et al., 2018).

HeLa cell culture growth conditions and maintenance were conducted according to our previously published protocol (Aboul-Soud et al., 2019). Cell proliferation was examined against an increasing concentration range of the crude recombinant IGF-1 obtained from IPTGinduced $(0.1 \mathrm{mM})$ E. coli cultures. HeLa cells were grown in a standard cell culture incubator at $37^{\circ} \mathrm{C}$ in $5 \% \quad \mathrm{CO}_{2}$ humidified air. Cells reaching approximately $75 \%$ confluence were treated with either $0,2,4$, or $8 \mu \mathrm{g} / \mathrm{ml}$ IGF- 1 crude protein solution. The capability of the reducing enzymes that are present in viable cells to convert 3-[4,5dimethylthiazol-2-yl]-2,5-

diphenyltetrazoliumbromide (MTT) to formazan crystals has been considered as a direct indicator of proliferative potential (Aboul-Soud et al., 2019).

\section{RESULTS AND DISCUSSION}

Recombinant protein technology relies primarily on the expression of proteins in various host organisms. In this context, E. coli has been advocated as an appropriate host for heterologous protein production ascribed by its cost-effectiveness, known genome sequence, ease and convenience of culturing and manipulation, and high-yield protein production (Aboutalebi et al., 2018). In this work, we employed a powerful RT-PCR technique to clone an $I G F-1$ cDNA from Egyptian buffalos and subsequently transformed it into E. coli JM109 strain for protein expression. IGF-1 that essentially functions as an endocrine hormone which is primarily secreted by hepatocytes and is subsequently transported to other organs (Laron, 2001).

Hence, we targeted liver tissues for the cloning of IGF-1 cDNA due to the expected high abundance of its mRNA. To our best knowledge, this is the first report on the cloning and protein expression of IGF-1 from Egyptian bovine population. Recently, the successful cloning of a
cDNA encoding IGF-1 protein from Indian goat has also been reported via RT-PCR strategy (Naicy et al., 2017). The caprine IGF-1 cDNA contained a 465-bp open reading frame (ORF) encoding IGF-1 protein composed of 154 amino acids, sharing 83-99\% identity range with other species and the highest identity with ruminants. Moreover, an RT-PCR-based approach has been employed for the cloning of a porcine IGF-1 receptor (IGF-1R) (Harumi et al., 2001); thereby proving its efficiency.

The ORF of 4.2-kb sequence was determined to encode a protein composed of 1367 amino acid residues showing sequence similarities of $95.2 \%$ and 98.1 to the rat and human IGF-1R, respectively (Harumi et al., 2001). Thermostable polymerases that are traditionally employed in PCR require a DNA template, whereas the RTPCR process primarily relies on RNA as a template. RNA quality in terms of purity and integrity are essential prerequisites for a successful RT-PCR (Beckler et al., 1996; AlSheikh et al., 2016). Hence, total RNA was firstly purified from the liver of Buffalos. Spectrophotometric RNA-yield determination was conducted at wavelengths 260 and $280 \mathrm{~nm}$. The obtained RNA samples exhibited an average A260/A280 ratio of approximately 1.8. The purified total RNA was of high quality as the profile of its $28 \mathrm{~S}$ and $18 \mathrm{~S}$ ribosomal bands exhibited no evidence of degradation. This was judged by a 2:1 in-gel intensity ratio observed in electrophoresis (data not shown).

Before PCR process, the obtained RT reaction (containing cDNA) was subjected to serial dilution $(5 x, 10 x, 15 x$ and $20 x)$ in order to dilute any potential contaminants that might exert inhibitory action on the activity of DNA polymerase. $I G F-1$-specific oligos (i.e., IGF-1-F and $I G F-1-R$ ) were designed according to a previous study (Fotsis et al., 1990) spanning its entire ORF with a theoretical size of 543bp. Pfu DNA polymerase was specifically utilized due to its intrinsic proofreading activity (Flaman et al., 1994). Agarose gel electrophoresis procedure has indicated the presence of a single and specific PCR amplicon, being resolved at a higher level than the 500bp (Figure 1). 


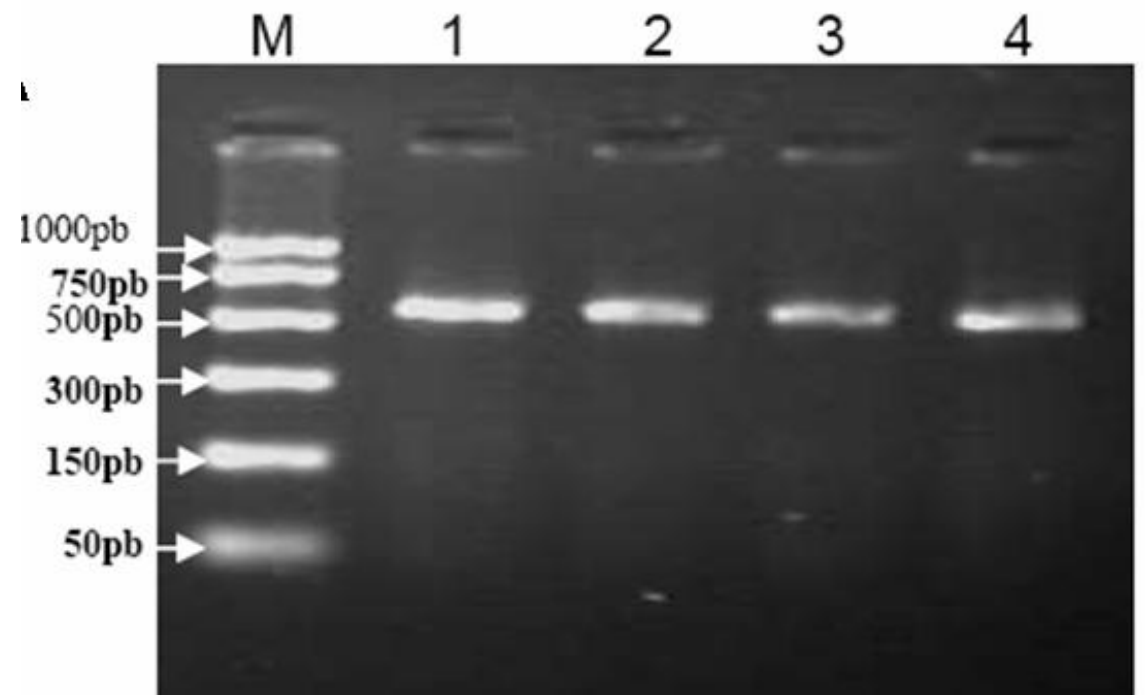

Figure 1. Gel electrophoresis of RT-PCR products of cattle $I G F-1$. Lane M represents DNA ladder, Lanes 1-4 represent PCR product single bands of an approximate size of 543bp corresponding to IGF- 1 cDNA in which the RT reaction was diluted 5, 10, 15 and 20 times, respectively, prior to using in PCR. Several trials have been carried out and the image depicted is a representative one.

Reverse transcription dilutions (20x, lanes from 1 to 4) single bands specific at the above size. Next, the obtained PCR products were purified by use of PCR Clean-Up Kit (Promega, WI USA). For the confirmation of the identity of the obtained amplicon, sequencing was carried out. To this end, the sequence of the PCR product was aligned to a reference bovine $I G F-1$ cDNA sequence that had previously been described (Fotsis et al., 1990). The pairwise alignment, as depicted in Figure 2, confirms that the cloned PCR product is aligned perfectly with the ORF region of bovine $I G F-1$ cDNA, as expected. Figure 3 represents the isolated $I G F-1$ cDNA confirming that the ORF of the isolated IGF-1 encodes a precursor protein with a predicted size of 154 aa spanning the entire ORF region; thereby agreeing with previously published work (Fotsis et al., 1990).

On confirmation of the identity of PCR product, direct cloning into the T-vector pTARGET ${ }^{\mathrm{TM}}$ was performed. The advantage of using this vector was two-fold: $i$ ) classified as a T-vector for cloning of PCR products that had been Atailed; ii) pTARGET $^{\mathrm{TM}}$ enabled the direct utilization for IGF-1 protein in mammalian cells expression studies, being a mammalian expression vector, by virtue of the presence of a constitutive promoter/enhancer called human cytomegalovirus (CMV). It additionally harbors the neomycin neomycin phosphotransferase (NPT) antibiotic resistance gene, as a selectable marker in mammalian cells. We have successfully attempted the cloning of IGF-1 PCR amplicon using pTARGET ${ }^{\mathrm{TM}}$-Vector system in competent E. coli JM109 strains.

After clean-up, the IGF-1 amplicon was A-tailed and subsequently cloned into pTARGET ${ }^{\mathrm{TM}}$ plasmid. Next, the recombinant plasmid harboring the IGF-I cDNA under the constitutive expression of CMV vector was transformed into E. coli JM109 high efficiency competent cells. The pTARGET ${ }^{\mathrm{TM}}$-Vector also includes the $ß$-galactosidase gene, whereby permitting the blue/white screening for recombinant colonies. Bona fide transformants were selected on LB/ampicillin/IPTG/X-Gal plates. Enough white colonies generally appeared in the selection plates, 24-hr post transformation indicative of the successful transformation of the $I G F-1$ insert. Colony PCR was performed and positive colonies were confirmed to harbor the $I G F-1$ insert as verified by the agarose gel electrophoresis band pattern of $\sim 500 \mathrm{bp}$ amplicons (data not shown).

Next, IGF-1 protein expression was studied by SDS-PAGE as depicted in Figure 4. Results clearly show that the IGF-1 protein has been successfully expressed in $E$. coli strains 
harboring the recombinant pTARGET $^{\mathrm{TM}}$ plasmid harboring $I G F-1$ insert. A specific IPTG-induced band corresponding to the expected $7.6 \mathrm{kDa}$ size of recombinant IGF-1 protein was evident in JM109 strains incubated with IPTG $(0.1 \mathrm{mM})$ at $37^{\circ} \mathrm{C}$ for $16 \mathrm{~h}$ (+IPTG, Figure 4$)$. By contrast, this band was completely absent in the uninduced JM109 strains (-IPTG, Figure 4). In this work, despite, the employed E. coli system, despite being characterized with quick and highthroughput production of soluble recombinant IGF-1 proteins, it resulted in the accumulation of insoluble proteins into inclusion bodies.
We optimized glucose concentration required for efficient IGF-1 recombinant protein expression level. Data presented in Figure 5 indicate that an initial glucose concentration of $10 \mathrm{~g} / \mathrm{l}$ is associated with maximal IGF-1 protein concentration and CDW of 3.5 and $6.2 \mathrm{~g} / \mathrm{l}$, respectively. Moreover, the crude IGF-1 protein has been verified to be biologically active as it exerted a dose-dependent proliferative effect on HeLa cell lines; with maximal proliferative effect observed at the concentration of $6 \mu \mathrm{g} / \mathrm{ml}$ (Figure $6)$.

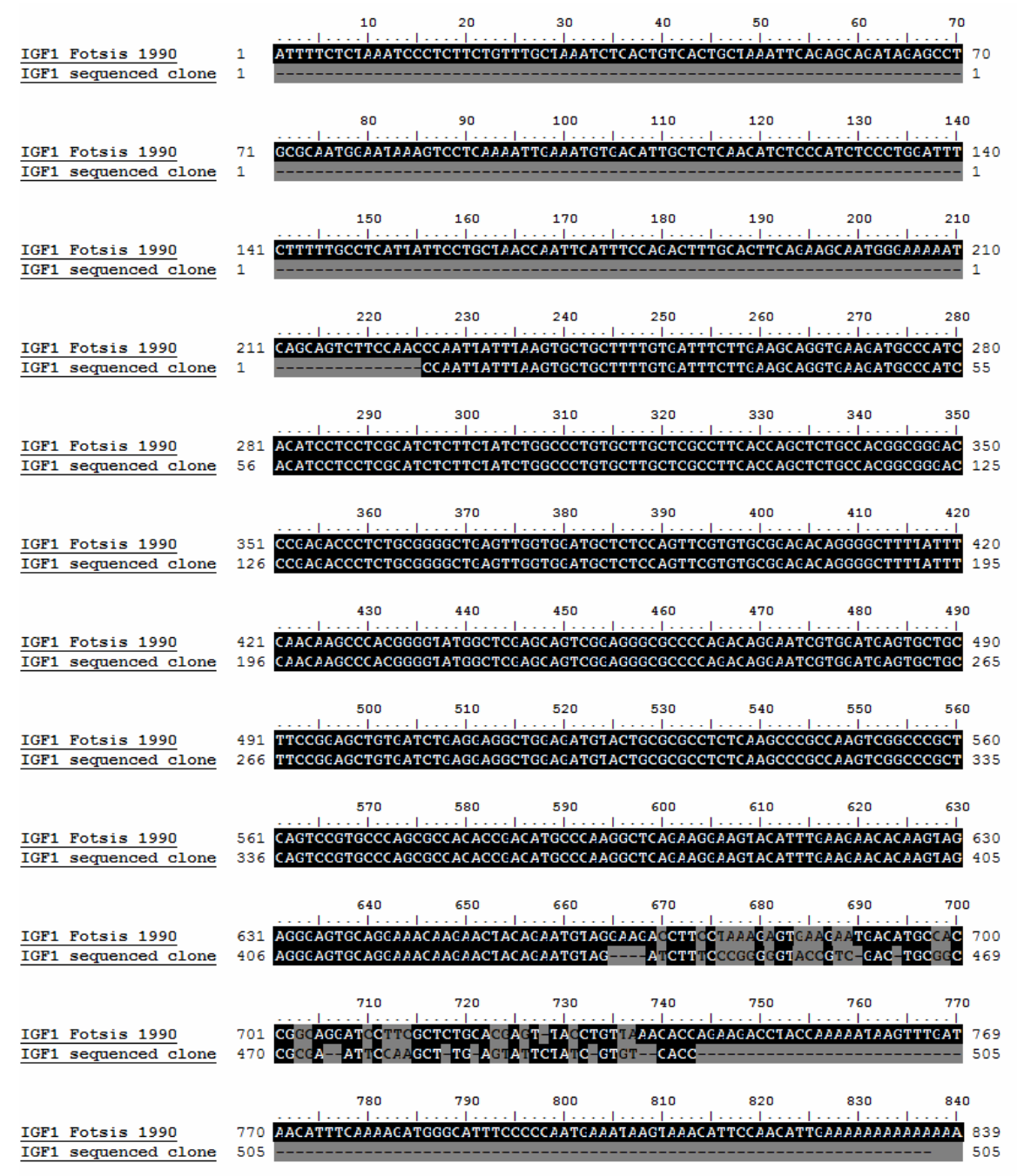

Figure 2. Pairwise sequence alignment of the amplified PCR product (lower) against a previously described bovine IGF-1 cDNA (upper) [NCBI GenBank accession no. X15726]. The alignment was performed with BioEdit Sequence Alignment Editor (Hall, 1999). The sequence of the PCR product clearly indicates that it is identical to the precursor of bovine $I G F-1$ open reading frame. Black shading indicates identical bases and grey shading indicates non-identical bases. 


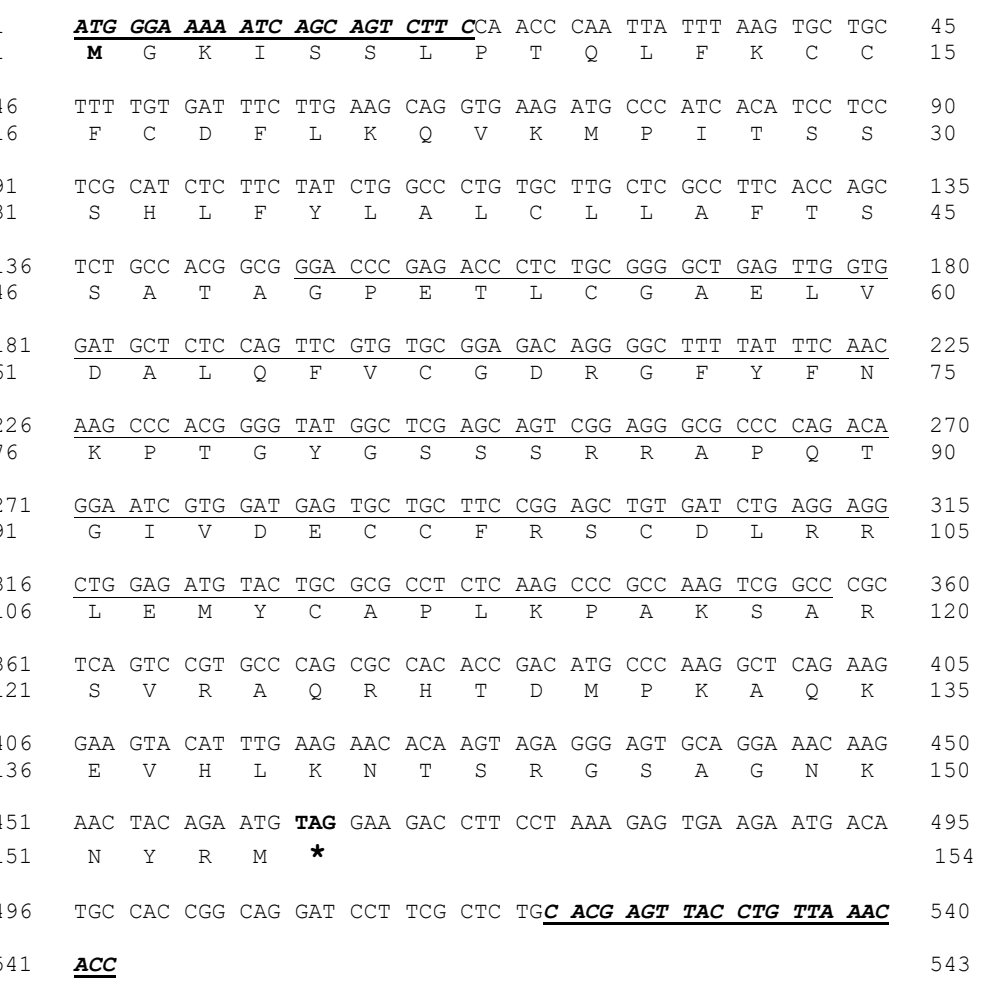

Figure 3. Nucleotide and deduced amino acid sequences of cloned bovine IGF-1 precursor cDNA; generated with BioEdit Sequence Alignment Editor. Bold underlined sequences denote sense $(I G F-1-F)$ and antisense (IGF-1-R) primers utilized for RT-PCR. The codon usage was optimized for mammalians; start codon $=$ ATG and stop codon $=$ TAG (denoted by an $*$ asterisk). The total sequence corresponds to an ORF length of 543 bp encoding 154 aa. The mature IGF-1 protein is outlined.

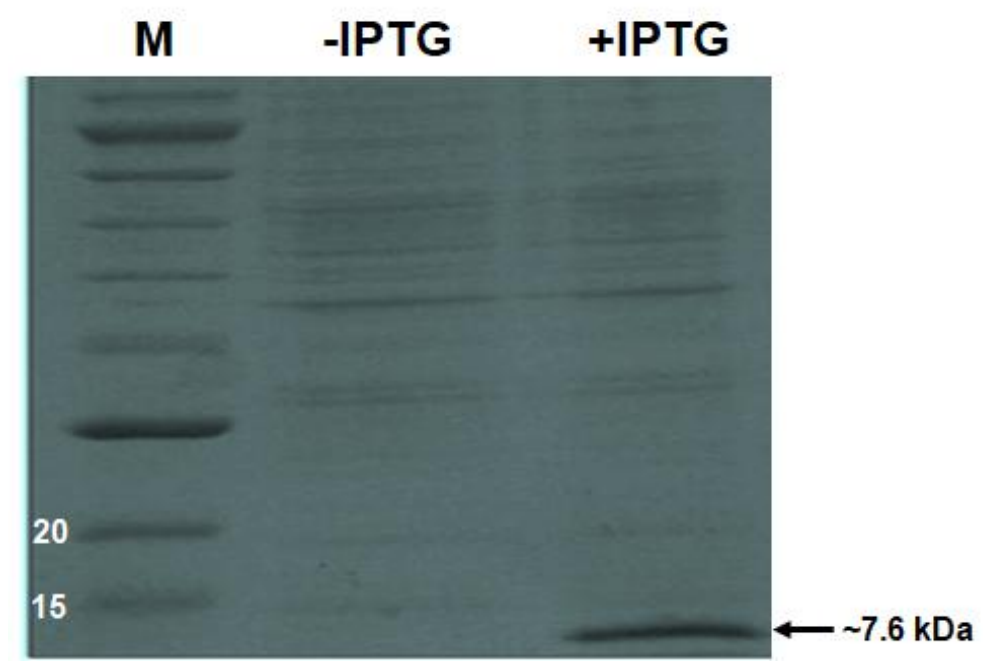

Figure 4. SDS-PAGE analysis of the expression of recombinant IGF-1 protein in E. coli JM109. M: indicate protein molecular-mass standards in $\mathrm{kDa}$; -IPTG: indicate the protein profile banding pattern of IGF-1-pTARGET-transformed JM109 strain without IPTG induction; +IPTG: indicate the protein profile banding pattern of IGF-1-pTARGET-transformed JM109 strain with IPTG induction (1mM) for 8h at $37^{\circ}$, exhibiting a specific $\sim 7.6 \mathrm{kDa}$ band, corresponding to the expression of recombinant IGF-1 protein. $10 \mu \mathrm{g}$ protein were loaded per lane and electrophoresed in $12 \%$ SDS-PAGE gel for $1 \mathrm{hr}$ at $100 \mathrm{~V}$ followed by overnight Coomassie Brilliant Blue R-250. Destaining was carried out using of methanol/ acetic acid solution according to standard procedure (Sambrook et al., 1989). 


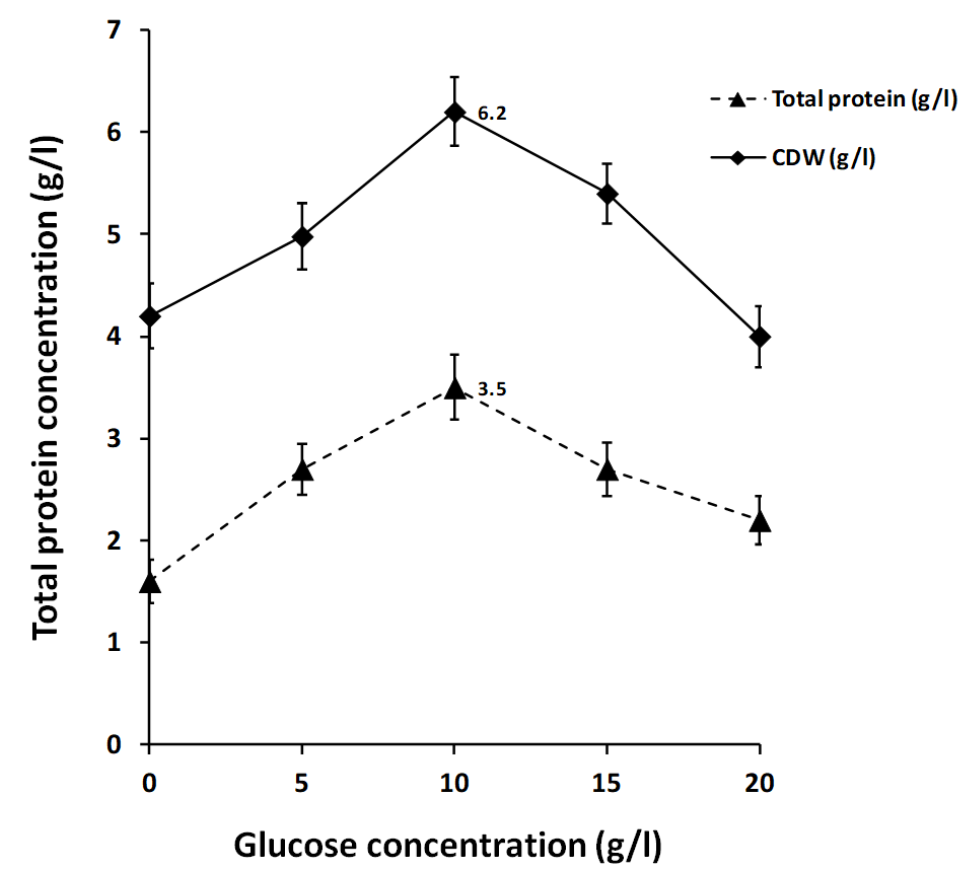

Figure 5. Effect of glucose concentration on protein production and E. coli biomass. Induction IPTG concentration was $0.1 \mathrm{mM}$, incubation temperature at $37^{\circ} \mathrm{C}$, OD at induction was 5.0 and incubation time was $16 \mathrm{~h}$ in LB broth supplemented with penicillin.

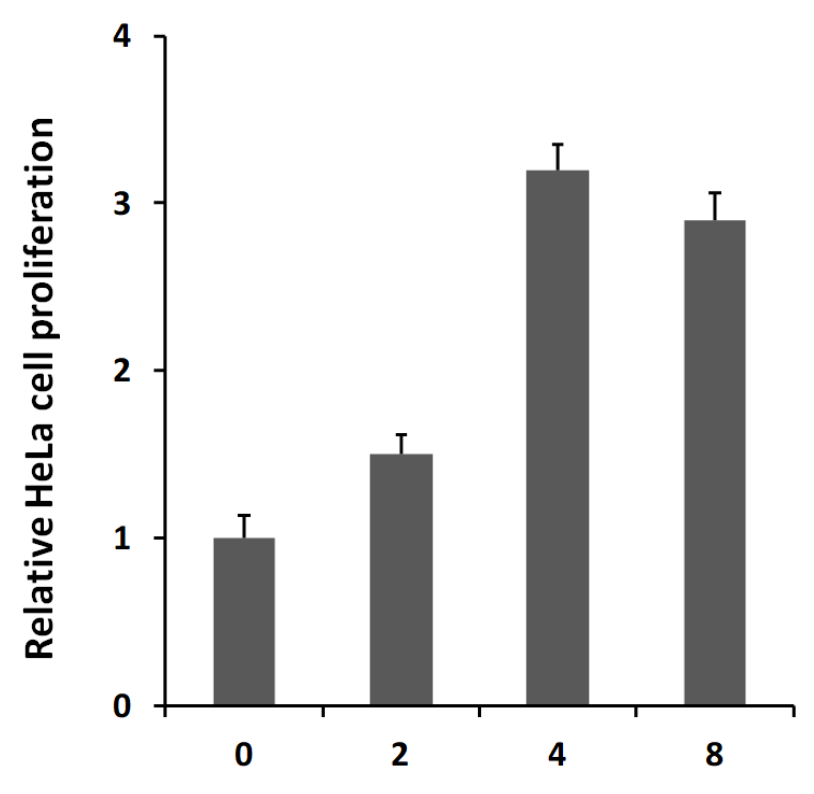

\section{Crude protein concentration $(\mu \mathrm{g} / \mathrm{l})$}

Figure 6. Biological effect of crude recombinant IGF-1 protein extracts on proliferation of HeLa cervical cancer cell lines. Error bars denote standard error on the mean (SEM) for three independent replications.

The known drawback of inclusion bodies has been overcome by researchers through engineering a fusion protein whose $\mathrm{N}$-terminal is flanked by a solubilization tag (i.e., amino acid motif), such as a polyhistidine-tag that typically consists of at least six histidine (His) residues. 
This approach thereby facilitates downstream purification of recombinant proteins fusion to achieve high purity with minimal structural damage exerted on the target protein (Terpe, 2003). This strategy has been recently employed for the production of soluble and biologically active human IGF-1 in E. coli Rosetta-gami (DE3) strain with high yield (Aboutalebi et al., 2018). In the current study, bovine IGF- 1 cDNA was cloned into pTARGET ${ }^{\mathrm{TM}}$ Mammalian Expression Vector System; thus enabling future endeavors to transfect mammalian cells with this recombinant construct, either stable or transient, in order to thoroughly study its biological activity in different systems. Expression in mammalian systems overcomes the problem of producing misfolded proteins, frequently encountered with prokaryotic hosts, due to the lack of functional posttranslational modification machinery (Xu et al., 2006).

In conclusion, the $I G F-1$ cDNA has successfully been cloned from bovine liver in pTARGET $^{\mathrm{TM}}$ vector and subsequently transformed it into $E$ coli JM109 strain. The recombinant IFG-1 protein has been successfully expressed at the expected size of $7.6 \mathrm{kDa}$. This should offer a valuable help for transecting the recombinant pTARGET $^{\mathrm{TM}}$ vector, harboring the IGF-1 cDNA insert, into mammalian cells. This is envisaged to facilitate high-throughput large-scale production of properly-folded recombinant IGF-1 protein, thereby enabling thorough investigation of its clinical and pharmaceutical effects both in vitro and in vivo.

\section{ACKNOWLEDGEMENT}

This project was funded by the National Plan for Science, Technology and Innovation (MAARIFAH), King Abdulaziz City for Science and Technology, Kingdom of Saudi Arabia, Award Number (11-BIO2119-02).

\section{REFERENCES}

ABOUL-SOUD MAM, A.L.; AMRI, M.Z.; KUMAR, A.; AL-SHEIKH, Y.A. et al. Specific cytotoxic effects of parasporal crystal proteins isolated from native Saudi Arabian Bacillus thuringiensis strains against cervical cancer cells. Molecules, v.24, p.506, 2019.
ABOUTALEBI F, LACHINANI L, KHAZAEI $\mathrm{Y}$, FOROUZANFAR $\mathrm{M}$, et al. An efficient method for bacterial production and activity assessment of recombinant human insulin like growth factor 1. Mol. Biol. Rep., v.45, p.19571966, 2018.

AL-SHEIKH, Y.A.; GHNEIM, H.K.; SOFTA, K.I.; AL-JOBRAN, A.A. et al. Expression profiling of selected microRNA signatures in plasma and tissues of Saudi colorectal cancer patients by qPCR. Oncol. Lett., v.11, p.14061412, 2016.

ANISIMOV, V.N.; BARTKE, A. The key role of growth hormone-insulin-IGF-1 signaling in aging and cancer. Crit. Rev. Oncol. Hematol., v.87, p.201-223, 2013

BARNER, C.; PETERSSON, M.; ENGSTRÖM, B.E.; HÖYBYE, C. Effects on insulin sensitivity and body composition of combination therapy with GH and IGF-1 in GH deficient adults with type 2 diabetes. Eur. J. Endocrinol., v.167, p.697-703, 2012.

BECKLER, G.; BHATIA, A.; BRISCO, P.; BRONDYK, W. et al. Protocols and applications guide: the source for discovery (Promega). 3.ed. [Madison]: Ken Doyle, 1996.

BEHL, R.; KAUL, R. Insulin like growth factor 1 and regulation of ovarian function in mammals. Indian J. Exp. Biol., 40, p.25-30, 2002.

BLUNDELL, T.L.; HUMBEL, R.E. Hormone families: pancreatic hormones and homologous growth factors. Nature, v.287, p.781-787, 1980.

BRISSENDEN, J.E.; ULLRICH, A.; FRANKE, U. Human chromosomal mapping of genes for insulin-like growth factors I and II ad epidermal growth factor. Nature, v.310, p.781-784, 1984.

CHOI, J.H.; LEE, S.J.; LEE, S.J.; LEE, S.Y. Enhanced production of insulin-like growth factor I fusion protein in Escherichia coli by coexpression of the down-regulated genes identified by transcriptome profiling. Appl. Environ. Microbiol., v.69, p.4737-4742, 2003.

DAVIS, M.E.; SIMMEN, R.C. Genetic parameter estimates for serum insulin-like growth factor I concentrations, and body weight and weight gains in Angus beef cattle divergently selected for serum insulin-like growth factor I concentration. J. Anim. Sci., v.84, p.2299-2308, 2006. 
DULL, T.J.; GRAY, A.; HAYFLICK, J.S.; ULLRICH, A. Insulin-like growth factor II precursor gene organization in relation to insulin gene family. Nature, v.310, p.777-781, 1984.

EWTON, D.Z.; ROOF, S.L.; MAGRI, K.A.; MCWADE, F.J. et al. IGF-II is more active than IGF-I in stimulating L6A1 myogenesis: greater mitogenic actions of IGF-I delay differentiation. J. Cell Physiol,. v.161, p.277-284, 1994.

FLAMAN, J.M.; FREBOURG, T.; MOREAU, V.; CHARBONNIER, F. et al. A rapid PCR fidelity assay. Nucl. Acids Res., v.22, p.32593260, 1994.

FLORINI, J.R.; EWTON, D.Z.; COOLICAN, S.A. Growth hormone and the insulin-like growth factor system in myogenesis. Endocr. Rev., v.17, p.481-517, 1996.

FOTSIS, T.; MURPHY, C.; GANNON, F. Nucleotide sequence of the bovine insulin-like growth factor I (IGF-I) and its IGF-IA precursor. Nucleic Acids Res., v.18, p.676, 1990.

FROESCH, E.R.; SCHMID, C.; SCHWANDER, J.; ZAPF, J. Actions of insulin-like growth factors. Ann. Rev. Physiol., v.47, p.443-467, 1985.

HALL, T.A. BioEdit: a user-friendly biological sequence alignment editor and analysis program for Windows 95/98/NT. Nucleic Acids Symp. Ser., v.41, p.95-98, 1999.

HARUMI, T.; MARUYAMA, K.; KAGAMI, H.; SANO, A. et al. Cloning of porcine IGF-1 receptor cDNA and detection of sequence polymorphisms using RT-PCR. Anim. Genet., v.32, p.386-389, 2001.

HAUGAARD, S.B.; ANDERSEN, O.; HANSEN, B.R.; OØRSKOV, H. et al. Insulinlike growth factors, insulin-like growth factorbinding proteins, insulin-like growth factorbinding protein-3 protease, and growth hormonebinding protein in lipodystrophic human immunodeficiency virus-infected patients. Metabolism, v.53, p.1565-1573, 2004.

HOLTHUIZEN, P.; VAN DER LEE, F.M.; IKEJIRI, K.; YAMAMOTO, M.; SUSSENBACH, J.S. Identification and initial characterization of a fourth leader exon and promoter of the human IGF-II gene. Biochem. Biophys. Acta, v.1087, p.341-343, 1990.
JAFARI, S.; BABAEIPOUR, V.; SEYEDI, H. A.; RAHAIE, M. et al. Recombinant production of mecasermin in E. coli expression system. Res. Pharmaceut. Sci., v.9, p.453-461, 2014.

JANSEN, M.; VAN SCHAIK, F.M.A.; RICKER, A.T.; BULLOCK, B. et al. Sequence of cDNA encoding human insulin-like growth factor I precursor. Nature, v.306, p.609-611, 1983.

LARON, Z. Insulin-like growth factor 1 (IGF-1): a growth hormone. Mol. Pathol., v.54, p.311316, 2001.

LIGHTEN, A.D.; MORRE, G.E.; WINSTON, R.M.L.; HARDY, K. Routine addition of human insulin-like growth factor-I ligand could benefit clinical in vitro fertilization culture. Hum. Reprod., v.13, p.3144-3150, 1998.

LOCATELLI, V.; BIANCHI, V.E. Effect of GH/IGF-1 on bone metabolism and osteoporsosis. Int. J. Endocrinol., v.2014, p. 235060,2014

LOWRY, O.H.; ROSEBROUGH, N.J.; FARR, A.L.; RANDALL, R.J. Protein measurement with the Folin phenol reagent. J. Biol. Chem., v.193, p.265-275, 1951.

LUCY, M.C. Regulation of ovarian follicular growth by somatotropin and insulin-like growth factors in cattle. J. Dairy Sci., v.83, p.1635-1647, 2000 .

MARKKULA, M.M.; MAKAREVICH, A.V. Insulin-like growth factor-I increases the ratio of proliferating cell nuclear antigen positive cells of in vitro produced bovine embryos. Theriogenology, v.55, p.433, 2001.

MESSING, J.; CREA, R.; SEEBURG, P.H. A system for shotgun DNA sequencing. Nucleic Acids Res., v.9, p.309-321, 1981.

NAICY, T.; VENKATACHALAPATHY, T.; ARAVINDAKSHAN, T.; RAGHAVAN, K.C. $e t$ al. cDNA cloning, structural analysis, SNP detection and tissue expression profile of the IGF-1 gene in Malabari and Attappady Black goats of India. J. Genet., v.96, p.307-312, 2017. 
PAWSCHE, C.H.; APPA RAO, K.B.C.; TOTEY, S.M. Effect of insulin-like growth factor-1 and its interaction with gonadotrobins on in vitro maturation and embryonic development, cell proliferation and biosynthetic activity of cumulus cells and granulosa cells in buffalo. Mol. Rec. Dev., v.49, p.277-285, 1998.

ROTWEIN, P. Structure, evolution, expression and regulation of insulin-like growth factors I and II. Growth Factors, v.5, p.3-18, 1991.

ROTWEIN, P.; POLLOCK, K.M.; DIDIER, D.K.; KRIVI, G.G. Organization and sequence of the human insulin-like growth factor I gene. Alternative RNA processing produces two insulin-like growth factor I precursor peptides. $J$. Biol. Chem., v.11, p.4828-4832, 1986.

SAMBROOK, J.; FRITSCH, E.F.; MANIATIS, T. Molecular cloning: a laboratory manual. 2.ed. New York: Cold Spring Harbor Laboratory Press, 1989. 412p.

SANGER, F.; NICKLEM, S.; COULSON, A.R. DNA sequencing using chain termination inhibitors. Proc. Natl. Acad. Sci. USA, v.74, p.5463-5467, 1977.

SPICER, L.J.; CHAMBERLAIN, C.S.; MACIEL, S.M. Influence of gonadotropins on insulin- and insulin-like growth factor-I (IGFI)induced steroid production by bovine granulosa cells. Domest. Anim. Endocrinol., v.22, p.237254, 2002.
STEWART, E.H.; ROTWEIN, P. Growth differentiation, and survival: multiple physiological functions for insulin-like growth factors. Physiol. Rev., v.76, p.1005-1026, 1996.

TERPE, K. Overview of tag protein fusions: from molecular and biochemical fundamentals to commercial systems. Appl. Microbiol. Biotechnol., v.60, p.523-533, 2003.

VELAZQUEZ, M.A.; SPICER, L.J.; WATHES, D.C. The role of endocrine insulin-like growth factor-I (IGF-I) in female bovine reproduction. Domest. Anim. Endocrinol., v.35, p.325-342, 2008.

WATSON, A.J.; WESTHUSIN, M.E.; WINGER, Q.A. IGF paracrine and autocrine interaction between conceptus and oviduct. $J$. Reprod. Fertil. Supp., v.54, p.303-315, 1999.

WONG, E.Y.; SEETHARAM, R.; KOTTS, C.E.; HEEREN, R.A. et al. Expression of secreted insulin-like growth factor-1 in Escherichia coli. Gene, v.68, p.193-203, 1988.

XU, Z.; ZHONG, Z.; HUANG, L.; PENG, L. et al. High level production of bioactive human beta-defensin-4 in Escherichia coli by soluble fusion expression. Appl. Microbiol. Biotechnol., v.72, p.471-479, 2006. 